Florida International University FIU Digital Commons

FCE LTER Journal Articles

FCE LTER

6-1-2014

\title{
A Review of the Effects of Altered Hydrology and Salinity on Vertebrate Fauna and Their Habitats in Northeastern Florida Bay
}

Jerome J. Lorenz

Audubon Florida Tavernier Science Center, jlorenz@audubon.org

Follow this and additional works at: https://digitalcommons.fiu.edu/fce_lter_journal_articles

Part of the Earth Sciences Commons

\section{Recommended Citation}

Lorenz, J.J.. 2013. A Review of the Effects of Altered Hydrology and Salinity on Vertebrate Fauna and Their Habitats in Northeastern Florida Bay. Wetlands DOI: 10.1007/s13157-013-0377-1

This material is based upon work supported by the National Science Foundation through the Florida Coastal Everglades Long-Term Ecological Research program under Cooperative Agreements \#DBI-0620409 and \#DEB-9910514. Any opinions, findings, conclusions, or recommendations expressed in the material are those of the author(s) and do not necessarily reflect the views of the National Science Foundation. This work is brought to you for free and open access by the FCE LTER at FIU Digital Commons. It has been accepted for inclusion in FCE LTER Journal Articles by an authorized administrator of FIU Digital Commons. For more information, please contact dcc@fiu.edu, jkrefft@fiu.edu. 


\section{A REVIEW OF THE EFFECTS OF ALTERED HYDROLOGY AND SALINITY}

2 ON VERTEBRATE FAUNA AND THEIR HABITATS IN NORTHEASTERN

3 FLORIDA BAY

4 Jerome J. Lorenz

5 Audubon Florida Tavernier Science Center, 115 Indian Mound Trail, Tavernier FL,

6 33070; email: jlorenz@ audubon.org; phone: 305-852-5092

8 ABSTRACT

9 Estuarine productivity is highly dependent on the freshwater sources of the estuary. In

10 Florida Bay, Taylor Slough was historically the main source of fresh water. Beginning in

11 about 1960, and culminating with the completion of the South Dade Conveyance System

12 in 1984, water management practice began to change the quantity and distribution of flow

13 from Taylor Slough into Northeastern Florida Bay. These practices altered salinity and

14 hydrologic parameters that had measurable negative impacts on vertebrate fauna and their

15 habitats. Here, I review those impacts from published and unpublished literature and

16 anecdotal observations. Almost all vertebrates covered in this review have shown some

17 form of population decline since 1984; most of the studies implicate declines in food

18 resources as the main stressor on their populations. My conclusion is that the diversion

19 of fresh water resulted in an ecological cascade starting with hydrologic stresses on

20 primary then secondary producers culminating in population declines at the top of the 21 food web. 
23 Key Words: Florida Bay, Everglades, Taylor Slough, water management, population 24 declines 
INTRODUCTION

26 Anthropogenic alterations in the quantity, timing and distribution of freshwater to

27 estuaries have had calamitous ecological consequences to these important habitats on a

28 global scale (Day et al. 1989). Declines in productivity at all trophic levels have been

29 well documented. Although some of these changes occur as cataclysmic events,

30 incremental deviations in the freshwater source tend to be more common (Day et al.

31 1989). These incremental changes result in more subtle ecological changes through time

32 that can go unobserved by the casual observer, and rarely are there rigorous data to

33 support scientific claims of ecological decline (Day et al. 1989). In south Florida, the

34 Florida Bay estuary has been relatively well studied and the chronological sequence of

35 water diversions from its main freshwater source, Taylor Slough, have been well

36 documented (Fourqurean and Robblee 1999). These provide for the possibility of a

37 thorough review of the impacts on higher trophic levels that occurred through time as a

38 result of this water diversion.

39 Florida Bay is divided into basins by numerous anastomosing carbonate mud

40 banks (Fourqurean and Robblee 1999). Lorenz (2000) grouped these basins into 4

41 distinct sub-regions based on a variety of physical and biological data. The Western and

42 Southern sub-regions were largely defined by diurnal tidal influences of the Gulf of

43 Mexico and the Atlantic Ocean, respectively. The Central sub-region was characterized

44 by low influence of diurnal tides and low freshwater input from the Everglades. The last

45 sub-region was defined as a large basin in the northeastern corner of Florida Bay

46 (Northeastern Basin) and several smaller sounds adjacent to this basin. Collectively,

47 these basins are referred to as the Northeastern Florida Bay sub-region (NEFB; Fig1). 
48 The hydrology and salinity of NEFB are heavily influenced by inflows of fresh water

49 from Taylor Slough (Light and Deneen 1994, McIvor et al 1994, Kotun and Renshaw this

50 issue). Beginning in 1960, and culminating with the completion of the South Dade

51 Conveyance System (SDCS) in 1984, water management practices began to heavily

52 influence flows through Taylor Slough into NEFB (Kotun and Renshaw this issue). The

53 multiple canals, levees, pumps and control structures that comprise the water

54 management system of southern Florida dramatically altered the quantity, timing and

55 distribution of freshwater flows from the Everglades, through Taylor Slough and into

56 NEFB (Kotun and Renshaw, this issue). The goal of this review is to outline the physical

57 changes that have occurred in the NEFB, followed by a detailed account of changes in

58 habitats, populations and assemblages of multiple vertebrate species (summarized in

59 Table 1).

60

61 REVIEW

62 Changes in Salinity and Hydrology

63 Kotun and Renshaw (this issue) demonstrated that a series of infrastructure

64 changes to the canal system and concurrent changes in water management practices

65 (Kotun and Renshaw this issue) resulted in sequential decrease in flow through Taylor

66 Slough into the Northeastern Basin. The overall result of these actions was that water

67 that once flowed through Taylor Slough and into the Northeastern Basin was diverted to

68 the L-31N/C-111 canal complex (Fig1) and was discharged into the small sounds that

69 make up the eastern extreme of NEFB and Manatee Bay to the northeast (Barrata and

70 Fennema 1989, Kotun and Renshaw; this issue). Kotun and Renshaw (this issue) 
71 describe how, historically, the long residence time of fresh water in the Northeastern

72 Basin acted as a buffer against increases in salinity during the dry season (December to

73 May) when inflows from Taylor Slough were relatively modest compared to wet season

74 (June - November) inflows. The majority of the discharge from the C-111 occurred in

75 proximity to US Highway 1 (US-1; Fig1), flowing southward into Long Sound (Fig1;

76 Barrata and Fennema 1989). From there, fresh water cascaded through Little Blackwater

77 Sound, Blackwater Sound, and Buttonwood Sound, thereby bypassing the Northeastern

78 Basin (Barrata and Fennema 1989, Kotun and Renshaw; this issue) and greatly reducing

79 the salinity buffering capacity of the Basin by keeping salinities low. The end result was

80 increased salinization throughout NEFB.

81 Although there are no historical salinity records dating back to the pre-drainage

82 era, several studies used physical models and paleoecological techniques to reconstruct

83 historical salinity patterns. McIvor et al. (1994) combined several physical models to

84 reconstruct salinity from 1965 - 1981 at a location in the Northeastern Basin near the

85 Taylor Slough outfall. They concluded that if Taylor Slough had remained in an

86 unaltered state, salinity would have been 20 to 30 psu lower than in its current state.

87 Several paleoecological studies of sediment core samples from Florida Bay

88 indicate that the Florida Bay in general had lower salinity than occurs today (Halley et al.

89 1994, Brewster-Wingard and Ishman 1999, Halley and Roulier 1999, Swart et al. 1999).

90 Molluskan skeletal remains found in those cores were from species with lower salinity

91 tolerance than those that occur at the same locations today. More specific to NEFB,

92 Meeder et al. (1996) quantified the rate of saltwater encroachment into the wetlands

93 between Florida Bay and the C-111 canal using paleoecological techniques. They 
94 concluded that the rate of saline intrusion was several times that indicated by sea level

95 rise alone and demonstrated that the rate of saline intrusion was correlated with canal 96 operation.

97 Marshall et al. (2008) combined the use of physical models with paleoecological 98 techniques. They used long-term hydrological and climatological empirical data with

99 paleoecological data to produce statistical models that could hindcast hydrologic patterns

100 in Taylor Slough, freshwater flows from Taylor Slough and salinity in Florida Bay.

101 These models indicate that flow from Taylor Slough was almost 4 times greater than

102 current values and that salinity in NEFB is currently $12-15$ psu higher than would have 103 occurred under the greater freshwater flow regime.

104 Marshall et al. (2008) also indicated that water levels in Taylor Slough were about $10515 \mathrm{~cm}$ higher and that hydroperiods were 4 times greater. Johnson and Fennema (1989) 106 indicated that prior to water management impacts, the mean difference between wet 107 season maximum and dry season minimum water levels was about $1 \mathrm{~m}$. By 1988, they 108 found the average difference to about $0.25 \mathrm{~m}$ due to lower wet season maximums and 109 higher dry season minimums. Kotun and Renshaw (this issue) present some data that 110 indicate more recent water management practices have ameliorated some of this

111 difference, however, it is still quite different than the pre-drainage system. Kotun and 112 Renshaw (this issue) also provide a detailed account of the changes in hydrology since 1131950 that indicate significant changes in water levels and hydroperiods in Taylor Slough. 114 Biological evidence also indicates that the salinity regime has changed 115 dramatically in NEFB. Vegetation surveys of the area between Florida Bay and the C-111 116 canal indicate a steady landward increase in the width of the dwarf red mangrove 
117 (Rhizophora mangle) zone into areas that were historically fresh water herbaceous

118 marshes (Egler 1952, Tabb et al. 1967, Ross et al. 2002). Ross et al. (2002) compared the

119 results of their survey to a 1948 survey performed by Egler (1952). The comparisons

120 indicated that the mangrove dominated area had expanded inland by as much as $3.3 \mathrm{~km}$

121 since the 1948 study, supplanting the pre-existing freshwater marshes. Ross et al. (1996)

122 stated that this rate of mangrove intrusion was greater than could be attributed to sea level

123 rise alone. Aerial surveys were used to confirm the observed changes in the plant

124 community of the ecotone region (Ross et al. 2002). Apparently, the canal system

125 reduced the pressure of the fresh water head resulting in more frequent and sustained salt

126 water intrusion into this area, which would eliminate saline sensitive herbaceous plants

127 and favor the expansion of the mangrove zone.

128 From 1993 to 2012, I collected monthly measurements of salinity along several

129 upstream-downstream transect lines in the wetlands north of NEFB. Coincidentally,

130 during a 1905 sailing cruise from Miami to Key West Florida (recounted in Gilpen-

131 Johnson et al. 2000), fresh water was found at one of these transect locations in late

132 March. Using measurements made closest to the same calendar date as that of the 1905

133 record (all were within 3 weeks of that date), I estimated the mean salinity at this location

134 for the late March-early April time period to be $18.5( \pm 2.4 \mathrm{se})$ psu for the period 1993-

135 2012. The National Oceanic and Atmospheric Administration (NOAA) operated five

136 rainfall gages in southern Florida that were active in both 1905 and from the period 1993-

1372005 (data after May 2005 were unavailable). Data from these rainfall gages indicated

138 that the 1905 hydrologic year (June-May) was a drought year. Non-Metric

139 Multidimensional Scaling of monthly rainfall from the NOAA gages indicated that there 
140 were 2 modern hydrologic years with spatially and temporally similar rainfall patterns to

141 those of 1905: 1997 and 2001. In late March-early April of those two years salinity was

14224 and $26 \mathrm{psu}$, respectively. These data suggest that regional rainfall patterns that

143 historically resulted in freshwater conditions on these wetlands well into the dry season

144 currently result in salinities that approach marine conditions.

145 Collectively, the studies cited above provide substantive evidence that the 146 ecotonal wetlands north of Florida Bay have experienced higher salinities, longer periods

147 of saline intrusion and shorter hydroperiods due to anthropogenic manipulation of water

148 resources. Anecdotal evidence to support these conclusions can be garnered from

149 testimonials from residents of the region prior to Everglades' drainage. Simmons and

150 Ogden (1998) document an eyewitness account of conditions along the northeastern

151 mainland coast of Florida Bay during the 1920's and 1930's. They reported that the

152 mangrove zone only extended about $100 \mathrm{~m}$ north from the bay in the vicinity of Long

153 Sound and Joe Bay, beyond which were freshwater glades. Dwarf mangrove forests

154 currently extend several kilometers inland at these locations (Ross et al. 2002). Simmons

155 and Ogden (1998) also report that many creeks that delivered fresh water to the

156 Northeastern Basin and southern Biscayne Bay are now filled in from lack of flow. As

157 part of the planning process for the creation of Everglades National Park (ENP), Beard

158 (1938) performed a wildlife reconnaissance within the proposed park boundary. He

159 identified the region between Florida City and Key Largo, east of US Highway 1, as

160 seasonal farmland. Currently, this area is dominated by dwarf mangroves (Ross et al

161 2002). Former farmland can be readily identified because the individual mangroves grow

162 in straight lines along the old furrows (Pers. Obs.). Water salinity is currently brackish to 
163 marine, which would result in soil salinity levels that would prohibit successful farming

164 today. Will (1984) provided an account of the construction of the Homestead Canal to

165 Cape Sable in 1922. His photographs clearly show freshwater plant species (e.g.

166 sawgrass, (Cladium jamaicense); royal palm, (Roystonea regia); Paurotis palm, (Paurotis

167 wrighti) in areas that are currently dominated by mangrove forests. Water salinity in

168 these areas currently ranges from about 10 to 50 psu (Pers. Obs.). Other reminiscences

169 from residents of the area indicate a decline in the spatial extent of freshwater wetlands

170 bordering Florida and Biscayne bays (Anonymous 1987). Furthermore, large freshwater

171 upwellings occurred from Marco Island to Virginia Key (Tebeau 1955, Audubon 1960,

172 Craighead 1971, Anonymous 1987) including several in Florida Bay that were active as

173 late as the 1970's (McIvor et al. 1994, Gulick 1995). Tebeau (1955) presented a

174 photograph of an artesian spring on Chockoloskee Island. That such upwellings no

175 longer exist indicates that the freshwater head pressure from the Everglades has declined

176 significantly.

178 Coastal Mangrove Prey Base Fishes

179 Historically there were large numbers of wading birds that nested in NEFB during

180 the dry season (Powell et al. 1989, Lorenz et al. 2002). The coastal mangrove habitats

181 (Fig 1) of Taylor Slough and the C-111 are critical foraging habitat for these wading

182 birds during the dry season nesting cycle (Powell et al. 1989, Lorenz et al. 2002). These

183 habitats may have historically been important nursery habitats for juvenile game fish

184 species (Lewis et al. 1988, Rutherford et al. 1986) and they are currently important

185 foraging habitats for game fish (Odum et al. 1982, Ley et al. 1989, Ley 1992, Faunce et 
186 al. 2002) especially during low water periods of the dry season. Following the

187 completion of the SDCS in 1984 (Kotun and Renshaw, this issue), roseate spoonbills,

188 (Platelea ajaja) nest numbers in NEFB began to steadily decline (discussed below).

189 Powell (1986) speculated that the reason for the decline was due to changes in food

190 resources related to water management practices. This hypothesis led to an extensive

191 multilevel ecological study of the relationship between hydrology and salinity in the

192 coastal mangrove habitats where these birds feed. Among the findings was that relatively

193 high salinity and highly variable salinity adversely affected primary production (Frezza et

194 al. 2007). These authors concluded that such declines in primary production would

195 adversely affect higher trophic levels. Lorenz (1999) demonstrated that prey fish

196 productivity was a function of complex interactions between water level, hydroperiod and

197 salinity. It was also found that lower, more stable salinity led to assemblages of fish

198 species that were more productive than at higher and more variable salinity (Lorenz and

199 Serafy 2006). Prey base fishes were also found to expand throughout ephemeral

200 mangrove habitat and increase their numbers throughout the wet season (Lorenz 2000)

201 and that high water levels and longer hydroperiods led to greater fish abundance at the

202 end of the wet season (Lorenz 1999, Lorenz 2000). During low water periods of the dry

203 season these fish become highly available to predators when the ephemeral wetlands dry

204 and fish become concentrated in the remaining deeper water habitats (Lorenz 2000,

205 Lorenz this issue). Fish were found to begin aggregating in the refuges when water levels

206 on the ephemeral wetlands dropped below $13 \mathrm{~cm}$ (Lorenz this issue) and that spoonbill

207 nesting success was dependent on water levels lower than $13 \mathrm{~cm}$ throughout their nesting

208 cycle (Lorenz this issue). Pulse discharges from the C-111 (for flood control purposes) 
209 during the nesting cycle raised water levels above $13 \mathrm{~cm}$, dispersed the prey base and

210 resulted in nest abandonment (Lorenz 2000, Lorenz this issue). These findings indicate

211 that the demonstrated operational effects of the upstream canal system include lowered

212 water levels, shortened hydroperiods, and increased salinity (Marshall et al 2008, Kotun

213 and Renshaw this issue); thus, it is clear that these operations also impacted productivity,

214 abundance and availability of prey fishes in the coastal mangrove wetlands of Florida 215 Bay.

217 Fisheries Species

218 Fisheries stocks in estuaries have been positively related to freshwater inflow

219 (Day et al. 1989a, Longley 1994). Likewise, diversion of flow from estuaries results in a

220 decline in fisheries stocks (Browder and Moore 1981, Day et al. 1989a). Although

221 freshwater inflows impact estuaries on multiple levels (Snedaker et al. 1977, Day et al.

222 1989b), anthropogenic changes in salinity regime in estuaries has been linked to a decline

223 in fisheries stocks (Flanagan and Hendrickson 1976, Browder and Moore 1981, Longley

224 1994). A commonly cited impact of increased salinity is disruption of nursery function in

225 estuarine systems (Snedaker et al. 1977, Browder and Moore 1981, Bradley et al. 1990,

226 Ley et al. 1999). Temporally and spatially extensive surveys of fish assemblages in the

227 wetlands north of NEFB reveal little indication that this habitat is currently a nursery for

228 fishery species (Ley et al. 1999, Lorenz 1999, Lorenz and Serafy 2006).

229 Rutherford et al. (1989) correlated spotted seatrout (Cynoscion nebulosus) harvest

230 in Florida Bay with rainfall in the southern Everglades two years earlier. Tilmant et al.

231 (1989a) found that red drum (Sciaenops ocellatus) recruitment into Florida Bay's fishery 
232 increased following years with increased runoff from the Everglades. Tilmant et al.

233 (1989b) indicated that larval recruitment and juvenile survival of common snook

234 (Centropomus undecimalis) in Florida Bay were enhanced in years with high fresh water

235 flows from the Everglades. These three studies were based on surveys taken by ENP

236 between 1958 and 1987. A common prey item of game fish as well as supporting its own

237 fishery, pink shrimp (Farfantepenaeus duorarum) harvested in Dry Tortugas fishery use

238 central and western Florida Bay as a nursery area (Browder, 1985). In an examination of

23914 years of combined harvest by quarter year, pink shrimp harvest was correlated with

240 Everglades water levels from the previous quarter (Browder 1985). Browder et al. (1999)

241 indicated that relatively high water temperature and low salinity regimes play a role in

242 whether basins in central Florida Bay contribute recruits to the fishery. Although these

243 studies examined fishery stocks for all of Florida Bay (not just the Northeastern Basin),

244 they indicate that increased runoff into Florida Bay created more favorable conditions for

245 recruitment of fishery species. Therefore, the escalating diversion of fresh water away

246 from Florida Bay starting in 1960 probably resulted in less robust fishery stocks than had

247 occurred prior to water management in the southern Everglades. Reports from fishers

248 corroborate this conclusion (Zieman et al. 1989, Gulick 1995).

249 The association between fish communities and submerged aquatic vegetation 250 (SAV) has been well documented since the late 1950's (Serafy 1992). In Florida Bay, 251 Rutherford et al. (1986) linked various game fish species to SAV type. Thayer et al. 252 (1987) and Ley (1992) characterized the fish community associated with mangrove 253 shorelines. Thayer and Chester (1989) and Sogard et al. (1989b) characterized fish 254 communities associated with various seagrass species in basin and mud bank habitats 
255 respectively. Massive seagrass die-offs occurred throughout Florida Bay during the late 256 1980's and early 1990's (Robblee et al. 1991). As an example of the link between fish 257 community structure and SAV type, Matheson et al. (1999) repeated the techniques of 258 Sogard et al. (1989) at bank sites impacted by the seagrass die-off and found dramatically 259 different community types. Likewise, Thayer et al. (1999) repeated the techniques of 260 Thayer and Chester (1989) and documented both a decline in seagrass abundance and 261 changes in the fish community in basin and channel habitats within the bay.

262 Zieman et al. (1989) suggested that the northern half of the Northeastern Basin 263 was dominated by the seagrass shoal grass (Halodule wrightii) in the late 1950's. Shoal 264 grass is a pioneering species that is capable of tolerating fluctuations in salinity (Zieman 265 et al. 1989). Between 1960 and 1983, shoal grass was gradually replaced by turtle grass 266 (Thalassia testudinum; Zieman et al. 1989), a species of seagrass that generally displaces 267 shoal grass under stenohaline conditions, but can not tolerate salinity fluctuations to the 268 same degree as shoal grass. Zieman et al. (1989) attributes this change to consistently 269 higher salinity in NEFB as a result of water diversion away from the coastal wetlands. 270 Zieman et al. (1989) related that, beginning in the late 1970's, fishers reported fewer 271 mullet in the Northeastern Basin because thick turtle grass beds were not as useful as 272 feeding areas as shoal grass beds.

273 Rutherford et al. (1986) sampled juvenile game fish throughout Florida Bay.

274 More than $80 \%$ of the juvenile snook collected were found in low salinity (mean 8.9 psu)

275 SAV environs dominated by Chara spp. and Utricularia spp. Juvenile spotted seatrout 276 were mostly (>80\%) collected from grass and shoal grass beds with a mean salinity of 27717.2 psu. Gilmore et al. (1983) found that snook depend on coastal fresh water and low 
278 salinity environments for their early life history stages. Wakeman and Wohlslag (1977;

279 in Longley 1994) reported optimum metabolic salinity for juvenile spotted seatrout was

28020 to 25 psu. Longley et al. (1994) reported that spotted seatrout density over vegetation

281 increased with salinity but decreased above 30 psu. Catch rates for snook in NEFB

282 declined from 1972 to 1984 while catch rates for spotted seatrout increased over the same

283 period (Rutherford et al. 1989). These changes may be the result of changes in dominant

284 SAV (Rutherford et al. 1986). These findings all suggest that salinity increases in the

285 Northeastern Basin due to water management have resulted in broad ecological changes.

286 With the completion of the SDCS in 1984, dry season flood control for

287 agricultural lands required out-of-season pulses of water to be delivered to the C-111

288 basin (Van Lent et al. 1993). These pulses resulted in temporary increases in water level

289 and salinity decreases in NEFB (Baratta and Fennema 1994). As a result, salinity

290 variability increased in NEFB after 1983. Serafy et al. (1997) demonstrated that water

291 management in southern Florida can result in lethally extreme salinity fluctuations for

292 many common fish species. Montague and Ley (1993) periodically sampled NEFB

293 macrophytes and benthic crustaceans in conjunction with a variety of physicochemical

294 parameters and found that high variation in salinity had a negative impact on the flora

295 and fauna examined. Ley (1992) also found that the standard deviation of mean salinity

296 was negatively correlated with fish biomass. Finally, Ley et al. (1994) concluded that the

297 diets of fishes in areas of high salinity variation were inferior to those of more stable

298 salinity environments. The authors speculated that higher variance in ambient salinity

299 resulted in reduced productivity in benthic plants and crustaceans resulting in lower

300 quality prey and lower biomass in fishes (Ley et al. 1994). Stable salinities had the 
301 opposite effect. These results indicate that the salinity pulses caused by water

302 management practices would be detrimental to plant, invertebrate and fish communities

303 in the Northeastern Basin.

304

305 Reptiles

306 Florida Bay is unique in this hemisphere in that it has three sympatric reptiles 307 adapted to estuarine conditions; the American crocodile (Crocodylus acutus), the 308 diamondback terrapin (Malaclemys terrapin) and the mangrove water snake (Nerodia

309 clarkii compressicauda), all of which live and reproduce in the Northeastern Basin

310 (Dunson and Mazzotti 1989). The south Florida population of American crocodiles was

311 never large (estimated to be between 1000 and 2000) but by 1970 it had declined to

312 between 200 to 400 individuals (Ogden 1978). In the 1930's, the nesting range of Florida

313 Bay's crocodile population included all of the NEFB and beyond to other regions of

314 Florida Bay (Ogden 1978). By 1970, the majority of nesting occurred in the mainland

315 coastal wetlands in the Northeastern Basin (Mazzotti 1999). Since then, the number of

316 nests and nest success rates in NEFB have remained almost constant (Mazzotti 1999).

317 Mazzotti (1999) indicated that decreased fresh water flow from upland sources to the

318 Northeastern Basin might have altered the salinity regime such that many historical

319 nesting sites became unsuitable based on the physiological needs of hatchlings (see

320 below). Interestingly, crocodiles have expanded their range and numbers within ENP

321 over the last 30 years but rather than expanding southward to historical nest locations,

322 Cape Sable (northwestern Florida Bay) has now become the population center (Mazzotti. 
323 This further reinforces that conditions in the Northeastern Basin has become unsuitable

324 for nesting crocodiles.

325 Mazzotti and Dunson (1984) found that different salinity regimes resulted in

326 different growth rates in hatchling crocodiles. Optimum growth was found to occur at 9

327 psu salinity (Dunson and Mazzotti 1989). Hatchling crocodiles failed to grow at 35 psu

328 even when provided ample food (Mazzotti and Dunson 1984) and mortality ensued under

329 these conditions (Dunson 1982). Once young crocodiles reached $200 \mathrm{~g}$ body weight,

330 they were tolerant of marine conditions (Mazzotti and Dunson 1984). Cumulatively,

331 these studies show that low salinity environments are conducive to hatchling growth

332 while marine conditions inhibit growth and crocodiles are physiologically unable to

333 osmoregulate until they are about $200 \mathrm{~g}$ (Dunson and Mazzotti 1989). Moler (1991)

334 found that when young-of-the-year crocodiles reach $200 \mathrm{~g}$ prior to the seasonal increase

335 in salinity (December), average survival through the dry season was almost $30 \%$ while it

336 was only $10 \%$ for those individuals less than $200 \mathrm{~g}$. These results indicate that increased

337 salinity in the Northeastern Basin as a result of water management would reduce survival

338 in hatchling crocodiles (Mazzotti 1999).

339 Operation of the SDCS may have impacted crocodile nesting in another way.

340 Since 1984, the SDCS has operated in flood control mode (Van Lent et al. 1999).

341 Following above average rainfall events, water is pumped southward so that upstream

342 urban and agricultural lands are drained quickly. These pulse releases temporarily result

343 in higher water levels along the creek habitats in Taylor Slough and south of the C-111

344 canal (Baratta and Fennema 1994), thereby flooding nests and making eggs inviable

345 (Mazzotti 1999). Nesting sites along these creeks are desirable for crocodiles because 
346 they have lower salinity and are more protected from wind and wave action than other

347 sites (Mazzotti 1989). The percentage of total nests found along creeks declined from

$34828 \%$ in the 1970's to 12\% in the 1980's and 7\% in the 1990's (Mazzotti 1999).

349 Population dynamics of the diamondback terrapin in Florida Bay have not been

350 well studied. The lower Florida Keys sub-species of terrapin, known as the mangrove

351 terrapin (Malaclemys terrapin rhizophorarum), is currently classified as rare by the state

352 of Florida (Wood 1997). The sub-species of Florida's west coast (Malaclemys terrapin

353 macrospilata) is also very limited in range and abundance (Milsap et al. 1990). In

354 Florida Bay terrapins nest and forage on and around mangrove islands. Similar to

355 crocodiles, hatchling mangrove terrapins provided with ample food exhibit optimum

356 growth at 9 psu salinity and fail to grow at 21 psu and higher if not provided some fresh

357 drinking water (Dunson and Mazzotti 1989). Hatchlings in Florida Bay can acquire

358 enough drinking water from rainfall to survive, however, increasing salinity does result in

359 physiological stress (Dunson and Mazzotti 1989). The water management projects of the

360 last four decades have increased the salinity in the Northeastern Basin and the terrapin

361 population may have been adversely affected as a result.

362 The mangrove water snake is highly resistant to dehydration due to low uptake of

363 salts while feeding and probably satisfies its fresh water intake by drinking rainwater

364 (Dunson and Mazzotti 1989). As a result, this species is well adapted to highly saline

365 environments (Dunson and Mazzotti 1989). There is no indication of adverse impacts on

366 the population as a result of water management. 
369 The Florida manatee (Trichechus manatus latirostris) is a federally listed 370 endangered species (O'Shea and Ludlow 1992) that feeds prodigiously on SAV, 371 consuming about $4 \%$ to $9 \%$ of it's body weight $(20-45 \mathrm{~kg})$ in about five hours of feeding 372 time each day (Bengston 1983). Manatees feed heavily on seagrasses but other SAV, 373 bank grasses, overhanging mangroves, and floating plant species are also major 374 components of their diet (O'Shea and Ludlow 1992). Movements and aggregations can 375 be correlated to some degree with the distribution of SAV (Hartman 1974). Although 376 manatees are common in marine habitats and tolerate hypersaline conditions, they are 377 most frequently encountered in brackish and fresh water environments (O'Shae and 378 Ludlow 1992). Worthy (1998) suggests that manatees may require regular access to fresh 379 or brackish water to meet osmoregulatory needs. In the 1930's, the Northeastern Basin 380 and associated fresh water creeks were believed to be the most important area for 381 manatees within the proposed boundary of ENP (Beard 1938). In subsequent years, the 382 low number of manatees within Florida Bay were attributed to lower fresh water inflows 383 (Hartman 1974, Odell 1979). Although the impact of water diversion away from Florida 384 Bay on the manatee population was probably minimal, the impact of the loss of such 385 prodigious grazers to the ecology of the Northeastern Basin may have been profound. 386 Changes in SAV communities in the Northeastern Basin may have occurred, in part, to a 387 reduction in grazing pressure by manatees.

388 Although there are no records available for the historic use of the Northeastern 389 Basin as a foraging ground for bottlenose dolphin (Tursiops truncatus), recent surveys 390 revealed very little activity in this region (Torres 2009). Given the decline of common 
391 prey items (as identified by Torres 2009) of dolphin in the Northeastern Basin, this

392 paucity of dolphin use may be a consequence of lack of prey items potentially associated

393 with the operation of the SDCS (see fishery species section).

395 Birds

396 The Florida Committee on Rare and Endangered Plants and Animals lists 16 397 species of bird that nest in Florida Bay (Rodgers et al. 1996). Most of these birds (11 398 species) are wading birds (order Ciconiiformes) and most are highly opportunistic

399 nesters. Wading birds nest in various locations throughout the Everglades system in both 400 estuarine and freshwater areas. Furthermore, birds that nest in the Everglades region may 401 nest in other locations throughout the southeastern United States (Bancroft et al. 1994) 402 and possibly other international locations. Although these birds may be very good 403 indicators of overall conditions of the entire Everglades landscape (Frederick and 404 Collopy 1989, Bancroft et al. 1994, Ogden 1994), their transient and intermittent use of 405 Florida Bay nesting sites, compounded with their frequent use of nearby fresh water 406 regions of the landscape complicates the evaluation of Florida Bay health using 407 population statistics for these species. There are, however, five species of birds listed by 408 the state of Florida as rare or endangered ( 2 are wading birds) that have distinct Florida 409 Bay populations and have been relatively well studied, thereby allowing for an evaluation 410 of recent environmental changes.

411 Several research projects have examined the population of nesting roseate 412 spoonbills in Florida Bay. This species was nearly extirpated in the early 1900's but, 413 once afforded protection from hunting, the population recovered. The number of 
414 spoonbills nesting in Florida Bay increased exponentially from the 1950's though the mid

415 1970's, reaching a peak of 1259 nests in 1978. Following the completion of the SDCS in

4161984 , nest numbers steadily declined to approximately $600-800$ nests in the 1980 's, 400-

417500 in the 2000's (Bay-wide nest counts were discontinued in 1992 - 1999) and less than

418350 since 2008 (Lorenz et al. 2002, Stone and Lorenz 2012). In NEFB, the decline was

419 even more pronounced dropping from 688 nests in 1978 to 20 nests in 2011 (Lorenz et al.

420 2002, Stone and Lorenz 2012). Lorenz et al. (2002) demonstrated that degradation of

421 foraging grounds is the most likely explanation for this decline. Lorenz et al. (2002) also

422 showed that nesting success production was 1.4 chicks per nest (c/n) prior to the SDCS

423 and $0.7 \mathrm{c} / \mathrm{n}$ following its completion (most wading bird studies consider a production rate

424 of $<1.0 \mathrm{c} / \mathrm{n}$ as a failing population). Studies of prey base fishes on their primary foraging

425 grounds in NEFB indicate a reduction in habitat productivity, prey abundance and prey

426 availability concurrent with the decline in nesting success and nest numbers and that

427 water management practices have caused abandonment of nests in NEFB (detailed above

428 under prey base fishes). Recent results from a banding and tracking study found that

429 spoonbills have a high degree of fidelity to their natal habitat when they reach breeding

430 age and that they can breed at least until 19 years of age with an estimated life

431 expectancy of 25 to 30 years (JJL, unpublished data). That the NEFB nesting population

432 is largely closed to immigration or emigration, and that they are not reproducing at a high

433 enough production rate to maintain numbers enough to keep up with mortality explains

434 the steady decline in NEFB. The root cause is that water management practices have

435 reduced prey parameters such that nesting spoonbills can not access enough prey to meet

436 the energetic demands of their chicks (Lorenz et al. 2009). Lorenz et al. (2009) 
437 demonstrated that spoonbills are an umbrella indicator for Florida Bay suggesting that

438 other piscivorous species are likely having the same difficulties.

439 The vast majority of the US great white heron population (Ardea herodias

440 occidentalis) is located in southern Florida with $65 \%$ of the population nesting in Florida

441 Bay (Powell and Bjork 1996). Great white herons are considered an estuarine species

442 that feeds almost exclusively on fish (Powell and Bjork 1996). In 1959, the number of

443 great white herons in Florida Bay was estimated to be between 800 and 900 individuals

444 (Powell et al. 1989). Intermittent surveys between 1959 and 1984 indicated that the

445 population remained fairly constant at about 900 individuals (Powell et al. 1989).

446 Hurricanes resulted in large-scale mortality in this species but the population was found

447 to be resilient and recovered quickly (Powell et al. 1989). Complete surveys have not

448 been performed since 1984, however, a three-year study of great white herons in the early

449 1980's indicated that nest production was much lower than similar records collected in

4501923 (Powell and Powell 1986). Powell and Powell (1986) also found that birds that

451 received supplemental food from humans had similar production rates to those of 1923

452 while those that were not supplemented had much lower production. They concluded

453 that foraging habitat quality had been reduced. Powell et al. (1989) speculated that water

454 diversion upstream from Florida Bay had negatively impacted the prey base thereby 455 explaining the reduced nesting success in herons.

456 The populations of eastern brown pelican (Pelecanus occidentalis carolinensis)

457 was delisted from the endangered species list due recovery across its range. This was not 458 the case in Florida Bay. Prior to 1976, the number of pelican nests in the state was 459 approximately 6000 (Nesbitt 1996), with about 850 in Florida Bay (Kushlan and Frohring 
460 1985). Statewide nest numbers increased steadily from that point; in 1989 there were 461 12,310 nesting pairs (Nesbitt 1996). Over this same period the number of nests in Florida 462 Bay steadily declined (Kushlan and Frohring 1985). Ogden (1993) counted 350 nests in 463 a 1993 survey. Prior to the completion of the SDCS, pelicans commonly nested in the 464 Northeastern Basin (Ogden 1993, JC Ogden, Pers. Comm.), however surveys of nesting 465 colonies in this region from 1995 to 2012 revealed little pelican nesting activity (Pers. 466 Obs., L. Oberhofer, ENP, Pers. Comm). Furthermore, nesting throughout Florida Bay 467 has become a rarity with multi-year gaps between nesting activity (Pers. Obs.) and 468 nesting activity isolated to the extreme western portion of the bay (Pers. Obs.). Pelicans 469 feed exclusively on fish (Nesbitt 1996) and Kushlan and Frohring (1985) hypothesized 470 that the reason for the decline in nesting in Florida Bay was a reduction in prey 471 availability. Although the pelican prey base was not investigated, changes in fish 472 community structure as a result of water diversion may support their hypothesis.

473 Ospreys (Pandion haliaetus) are large raptors that prey almost exclusively on fish.

474 Most North American osprey populations seriously declined in the 1950's and 1960's as a 475 result of pesticide contaminants in the environment, however, the Florida Bay population 476 remained largely unaffected (Ogden 1977). While most other osprey populations 477 recovered during the 1970's and 1980's (due largely to legislation that restricted 478 environmentally damaging pesticides), the Florida Bay population declined (Poole 1989).

479 In the late 1960's and early 1970's there were about 200 pairs of nesting osprey in Florida 480 Bay (Ogden 1993). Intermittent nesting surveys taken in the 1970's indicated a steady 481 decline in nest numbers and, by 1993, there were only 70 nests in Florida Bay; a 58\% 482 decline from 20 years earlier (Ogden 1993). Much of the loss occurred in NEFB (Pers 
483 Obs, J. Ogden, Pers Comm). Over the same time period, nest success per attempt also 484 declined (Ogden 1993). These declines in number of nests and nesting success coincide 485 with major changes in water delivery to the Bay. During the 1986-87 nesting season, 486 Bowman et al. (1989) compared success of ospreys that nested on the main line Florida 487 Keys with those of Florida Bay. They found that nesting ospreys that foraged exclusively 488 in Florida Bay had significantly lower nest production than those that nested along the 489 Keys. By observing nests that allowed for foraging in both the Bay and the Atlantic 490 Ocean, Bowman et al. (1989) demonstrated that foraging flights toward the ocean were 491 more frequently successful than flights toward the bay. The authors concluded that 492 Florida Bay ospreys experienced decreased reproductive success due to an inadequate 493 food supply.

494 Similar to the osprey, the southern bald eagle (Haliaetus leucocephalus 495 leucocephalus) was federally listed as a result of environmental contaminants, but the 496 Florida Bay population was largely unaffected (Curnutt 1996, Baldwin et al. 2012). 497 Surveys of Florida Bay's nesting population of bald eagles began in 1958 (Curnutt 1991). 498 An analysis of the territoriality of eagles in Florida Bay from 1958 to the mid-1980's 499 indicated that the Bay is largely saturated and number of territories remained remarkably 500 constant (Curnutt 1991, Robertson 1993). Up to 30 territories were documented with 80501 100\% occupancy during the period (Baldwin et al. 2012). Beginning in the mid-1980's 502 (coinciding with the completion of the SDCS) the number of occupied territories began to 503 decline reaching a low of just 50\% occupancy in 2003 and 2004 (Baldwin et al. 2012). 504 Most of the abandoned territories were in NEFB; currently only one of the seven historic 505 territories in NEFB is active (ENP data, L. Oberhofer Pers. Comm.). Nests in other 
506 regions of the Bay continue to be highly productive compared to other eagle population

507 around North America (Baldwin et al. 2012). Although bald eagles principally feed on

508 fish, they are opportunistic feeders (Curnutt 1996). In Florida Bay, eagles supplement

509 their diet with terrapins, a variety of birds, and carrion (Robertson 1993). Also, bald

510 eagles are well known for thieving meals from ospreys through harassment

511 (kleptoparasitism). The plasticity of the eagles diet and the opportunistic nature of

512 foraging makes the observed decline particularly alarming given that this consummate

513 generalist apparently can not successfully raise young in NEFB.

515 Conclusions

$516 \quad$ Faunal studies in Florida Bay strongly suggest that water management practices

517 (starting in 1960 but culminating in 1984 with the completion and operation of the

518 SDCS) have had a profound impact on many animal populations. Many investigations

519 demonstrated a decline in reproductive success coincident with the physical and

520 ecological changes in the coastal wetlands. Most of the investigations implicated food

521 stresses as a cause for the observed changes in higher trophic levels. Collectively, the

522 studies reviewed imply declining success of vertebrate species in the Northeastern Basin

523 through an ecological cascade set in motion by upstream water management practices.

524 The cascade began with the increasing diversion of water away from its natural course

525 over the last several decades (Kotun and Renshaw this issue). The resulting alteration in

526 hydrology and salinity of NEFB altered the plant communities within the basin and

527 adjacent coastal wetlands. Plant and fish communities changed in response to the altered

528 dynamic environment and in response to each other. The result was a lowering of the 
529 quality of the forage base for vertebrate species, culminating in their inability to acquire

530 enough food in the region to maintain their populations.

\section{ACKNOWLEDGEMENTS}

533 The author would like to thank John Kipp, Lori Oberhofer, Sonny Bass and especially the

534 late John C. Ogden for their contributions to my understanding of the subject matter.

535 This publication was produced as part of a special issue devoted to investigating the

536 ecological response of over 20 years of hydrologic restoration and active management in

537 the Taylor Slough drainage of Everglades National Park. Support for this special issue

538 was provided by; the Everglades National Park, the Southeast Environmental Research

539 Center, the Florida Coastal Everglades Long-Term Ecological Research program

540 (National Science Foundation cooperative agreement \#DBI-0620409), the Everglades

541 Foundation and the South Florida Water Management District.

543 LITERATURE CITED

544 Anonymous (1987) Along the Florida Reef:1871. In: Tales of Old Florida. Castle, $545 \quad$ Seacaucus, pp 265-309.

546 Audubon JJ (1960) Audubon and his journals, Vol 2. Dover Publications, New York.

547 Baldwin JD, Bosley JW, Oberhofer L, Bass OL, Mealey BK (2012) Long term changes, 548 1958-2010, in the reproduction of bald eagles of Florida Bay, southern coastal 549 Everglades. Journal of Raptor Research 46:336-348.

550 Bancroft G, Strong AM, Sawicki RJ, Hoffman W, Jewell SD (1994) Relationships among 551 wading bird forage patterns, colony locations, and hydrology in the Everglades In: 
552 Davis SM, Ogden JC (eds) Everglades: the ecosystem and its restoration. St. Lucie 553 press, Delray Beach, pp 615-658.

554 Baratta AM, Fennema RJ (1994) The effects of wind, rain, and water releases on the 555 water depth and salinity of northeast Florida Bay. Bulletin of Marine Science 54:1072.

556 Beard DB (1938) Everglades National Park project wildlife reconnaissance. United

557 States Department of the Interior, National Park Service, Everglades National Park, 558 Homestead.

559 Bengston JL (1983) Estimating food consumption of free-ranging manatees in Florida.

560 Journal of Wildlife Management. 47:1186-1192.

561 Bowman RG, Powell GVN, Hovis JA, Kline NC, Wilmers T (1989) Variations in

562 reproductive success between subpopulations of the osprey (Pandion haliaetus) in south

563 Florida. Bulletin of Marine Science 44:245-250.

564 Bradley PM, Kjerfve B, Morris JT (1990) Re-diversion salinity change in the Cooper

565 River, South Carolina: ecological implications. Estuaries 13:373-379.

566 Brewster-Wingard GL, Ishman SE (1999) Historical trends in salinity and substrate in

567 cental Florida Bay: a palioecological reconstruction using modern analogue data.

568 Estuaries 22:269-383.

569 Browder JA, Moore D (1981) A new approach to determining the quantitative 570 relationship between fishery production and the flow of fresh water to estuaries.

571 Proceedings on the national symposium on fresh water inflow to estuaries. Vol 1. U.S.

572 Fish and wildlife service, Office of biological services. FWS/OBS-81/04:403-430. 
573 Browder JA, (1985) Relationship between pink shrimp production on the Tortugas

574 fishing grounds and water flow patterns in the Florida Everglades. Bulletin of Marine

$575 \quad$ Science 37:839-856.

576 Browder JA, Gleason PJ, and Swift DR (1994) Periphyton in the Everglades: spatial 577 variation, environmental correlates and ecological implications. In: Davis SM, Ogden

578 JC (eds) Everglades: the ecosystem and its restoration. St. Lucie press, Delray Beach, $579 \quad$ Florida, pp 379-418.

580 Browder JA, Restrepo VR, Rice JK, Robblee MB, Zein-Eldin Z (1999) Environmental 581 influences on potential recruitment of pink shrimp, Farfantepenaeus duorarum, from 582 Florida Bay nursery grounds. Estuaries 22:484-499.

583 Craighead FC (1971) The trees of south Florida. University of Miami Press, Miami.

584 Curnutt JL (1996) Southern bald eagle. In: Rodgers JA, Kale HW, Smith HT (eds) Rare 585 and endangered biota of Florida, volume 5: birds. University of Florida Press, 586 Gainesville, pp 179-187.

587 Day JW, Hall CAS, Kemp WM Yanez-Arencibia A (1989a) Estuarine Fisheries. In: Day 588 JW, Hall CAS, Kemp WM, Yanez-Arencibia A (eds) Estuarine ecology. John Wiley $589 \&$ Sons, New York, pp 479-511.

590 Day JW, Hall CAS, Kemp WM and Yanez-Arancibia A (eds). (1989b) Estuarine 591 ecology. John Wiley and Sons, New York.

592 DeAngelis DL, Loftus WF, Texler JC Ulanowicz RE (1997) Modeling fish dynamics and 593 effects of stress in a hydrologically pulsed ecosystem. Journal of Aquatic Ecosystem $594 \quad$ Stress and Recovery 6:1-13. 
595 Dunson WA (1982) Salinity relations of crocodiles in Florida Bay. Copeia 1982:374596385.

597 Dunson WA, Mazzotti FJ (1989) Salinity as a limiting factor in the distribution of reptiles

598 in Florida Bay: a theory for the estuarine origin of marine snakes and turtles. Bulletin

599 of Marine Science 44:229-244.

600 Egler FE (1952) Southeast saline Everglades vegetation. Vegetatio 3:213-265.

601 Eisler R (1987) Mercury hazards to fish, wildlife, and invertebrates: a synoptic review.

602 U.S. Fish and Wildlife Service Biological Report 85.

603 Faunce CH, Lorenz JJ, Ley JA, Serafy JE (2002) Size structure of grey snapper (Lutjanus

604 griseus) within a mangrove "no-take" estuary. Bulletin of Marine Science 70:20116052016.

606 Frederick PC, Collopy MW (1989a) Nesting success of five ciconiiform species in 607 relation to water conditions in the Florida Everglades. Auk 106:625-634.

608 Frederick PC, Collopy MW (1989b) The role of predation in determining reproductive 609 success of colonially nesting wading birds in the Florida Everglades. Condor 91:860$610 \quad 867$.

611 Frederick PC, Loftus WF (1993) Responses of marsh fishes and breeding wading birds to 612 low temperatures: a possible behavioral link between predator and prey. Estuaries $613 \quad 16: 198-215$

614 Frezza PE, Canedo LC, Lorenz JJ (2007) Relationships between submerged aquatic 615 vegetation abundance and salinity variability within the coastal mangrove zone of 616 northeastern Florida Bay. Estuarine Research Federation Biennial meeting, Providence $617 \quad$ RI, USA. 
618 Gilmore RG, Donohoe CJ, Cooke DW (1983) Observations on the distribution and

619 biology of east-central Florida populations of the common snook, Centropomus

620 undecimalis. Florida Scientist Special Suppliment 45:313-336.

621 Halley RB, Swart PK, Dodge RE, Hudson JH (1994) Decade-scale trend in sea water

622 salinity revealed ${ }^{18} \mathrm{O}$ analysis of Montastraea annularis annual growth bands. Bulletin

623 of Marine Science 54:670-678.

624 Halley RB, Roulier LM (1999) Reconstructing the history of eastern and central Florida

625 Bay using mollusk-shell isotope records. Estuaries 22:358-368.

626 Hartman DS (1974) Distribution, status, and conservation of the manatee in the United

627 States. National Technological Information Service PB81-140725, Springfield, 628 Virginia.

629 Johnson RA, Fennema RA (1989) Conflicts over flood control and wetland preservation

630 in the Taylor Slough and eastern panhandle basins of Everglades National Park.

631 Wetlands: Concerns and Successes. American Water Resources Association, pp 451632462.

633 Kotun and Renshaw, this issue of Welands. Taylor Slough hydrology: 50 years of water 634 management, 1960-2010.

635 Kushlan JA, Frohring PC (1985) Decreases in the brown pelican population in southern 636 Florida. Colonial Waterbirds 8:83-95.

637 Lewis RR, Gilmore RG, Crewz DW, Odum WE (1988) Mangrove habitat and fishery 638 resources of Florida. In: Florida Aquatic Habitat and Fishery Resources, Florida 639 Chapter of the American Fisheries Society, Eustis, pp 281-336. 
640 Ley JA (1992) Influence of freshwater flow on the use of mangrove prop-root habitat by 641 fishes. Dissertation, University of Florida.

642 Ley JA, McIvor CC, Montague CL (1999) Fishes in mangrove prop-root habitats of 643 northeastern Florida Bay: distinct assemblages across and estuarine gradient. 644 Estuarine, Coastal and Shelf Science 48:701-723.

645 Ley JA, Montague CL, McIvor CC (1994) Food habits of mangrove fishes: a comparison 646 along estuarine gradients in northeastern Florida Bay. Bulletin of Marine Science $647 \quad 54: 881-889$.

648 Light SS, Dineen JW (1994) Water control in the Everglades: a historical perspective. In:

649 Davis SM, Ogden JC (eds) Everglades: the ecosystem and its restoration, St. Lucie $650 \quad$ Press, Delray Beach pp 47-84.

651 Loftus WF, Eklund AM (1994) Long-term dynamics of an Everglades small-fish 652 assemblage. In: Davis SM, Ogden JC (eds) Everglades: the ecosystem and its 653 restoration, St. Lucie Press, Delray Beach, pp 461-483.

654 Longley WL (ed) (1994) Freshwater inflows to Texas bays and estuaries: ecological 655 relationships and methods for determination of needs. Texas Water Development 656 Board and Texas Parks and Wildlife Department, Austin.

657 Lorenz JJ (1999) The response of fishes to physicochemical changes in the mangroves of 658 northeast Florida Bay. Estuaries 22:500-517.

659 Lorenz JJ (2000) Impacts of water management on roseate spoonbills and their piscine 660 prey in the coastal wetlands of Florida Bay. Dissertation, University of Miami.

661 Lorenz JJ, Ogden JC, Bjork RD, Powell GVN (2002) Nesting patterns of roseate 662 spoonbills in Florida Bay 1935-1999: implications of landscape scale anthropogenic 
663 impacts. In: Poter JW, Porter KG (eds) The Everglades, Florida Bay and the coral reefs 664 of the Florida Keys: An ecosystem sourcebook, CRC Press, Boca Raton, pp. 555-598,

665 Lorenz, JJ, Serafy JE (2006) Changes in the demersal fish community in response to 666 altered salinity patterns in an estuarine coastal wetland: implications for Everglades and 667 Florida Bay restoration efforts. Hydrobiologia 569:401-422.

668 Lorenz, JJ, Langan-Mulrooney B, Frezza PE, Harvey RG, Mazzotti FJ (2009) Roseate 669 spoonbill reproduction as an indicator for restoration of the Everglades and the 670 Everglades estuaries. Ecological Indicators 9S:S96-S107.

671 Lorenz this issue. The relationship between water levels, prey availability and 672 reproductive success in roseate spoonbills utilizing a seasonally flooded wetland as a 673 forage area while nesting in Florida Bay

674 Marshall FE, Wingard GL, Pitts P (2008) A simulation of historic hydrology and salinity 675 in Everglades National Park: coupling paleoecologic assemblage data with regression 676 models. Estuaries and Coasts DOI 10.1007/s12237-008-9120-1.

677 Mazzotti FJ, Dunson WA (1984) Adaptations of Crocodylus acutus and Alligator 678 mississippians for life in saline water. Comparative Biochemistry and Physiology 679 79A:641-646.

680 Mazzotti FJ (1999) The American crocodile in Florida Bay. Estuaries 22:552-561.

681 McIvor CC, Ley JA, Bjork RD (1994) Changes in freshwater inflow from the Everglades 682 to Florida Bay including effects on the biota and biotic processes: a review. In: Davis 683 SM, Ogden JC (eds) Everglades: the ecosystem and its restoration, St. Lucie Press, 684 Delray Beach, pp 117-146. 
685 Meeder JF, Ross MS, Telesnicki G, Ruiz PL (1996) Vegetation analysis in the C686 111/Taylor Slough basin. Final Report to the South Florida Water Management District 687 (Contract C-4244), West Palm Beach.

688 Milsap BA, Gore JA, Runde DE, Cerulean SI (1990) Setting priorities for the 689 conservation of fish and wildlife species in Florida. Wildlife Monograph No. 111.

690 Moller PE (1991) American crocodile population dynamics. Final report for study 691 number 7532, Bureau of Wildlife Research, Florida Game and Freshwater Fish 692 Commission, Tallahassee.

693 Montague CL, Ley JA (1993) A possible effect of salinity fluctuation on abundance of 694 benthic vegetation and associated fauna in northeastern Florida Bay. Estuaries 16:703695717.

696 Nesbitt SA (1996) Eastern brown pelican. In: Rodgers JA, Kale HW, Smith HT (eds)

697 Rare and endangered biota of Florida, volume 5: birds. University of Florida Press, 698 Gainesville, pp 144-155.

699 Odell DK (1979) Distribution and abundance of marine mammals in the waters of 700 Everglades National Park. In: Proceedings of the Conference on Science and Research, 701 volume 5(1) of National Park Service Series. New Orleans pp 673-678.

702 Odum WC, McIvor CC, Smith TJ (1982) The ecology of mangroves of south Florida: a 703 community profile. U.S. Fish Wildlife Service Office of Biological Services 704 FES/OBS-81-24.

705 Ogden JC (ed) (1977) Transactions of the North American Osprey Research Conference. 706 Transaction and Proceeding of the Service No. 2, U.S. National Park Service, pp 143$707 \quad 151$. 
708 Ogden JC (1978) Status and nesting biology of the American crocodile, Crocodylus

709 acutus, (Reptilia, Crocodilidae) in Florida. Journal of Herpetology 12:183-196.

710 Ogden JC (1993) Florida Bay vertebrates: status reports for osprey, roseate spoonbill,

711 brown pelican and northwestern wading bird colonies. Everglades National Park, 712 Homestead.

713 Ogden JC (1994) A comparison of wading bird nesting colony dynamics (1931-1946 and 714 1974-1989) as an indication of ecosystem condition in the southern Everglades. In:

715 Davis SM, Ogden JC (eds) Everglades: the ecosystem and its restoration. St. Lucie 716 press, Delray Beach, pp 533-570.

717 O'Shea TJ, Ludlow ME (1992) Florida Manatee. In: S. R. Humphrey (ed.) Rare and

718 Endangered Biota of Florida Vol I. Mammals. University Press of Florida, 719 Gainesville, pp 190-200.

720 Poole AF (1989) Ospreys: a natural and unnatural history. Cambridge, New York.

721 Powell GVN, Powell AH (1986) Reproduction by great white herons Ardea herodias in

722 Florida Bay as an indicator of habitat quality. Biological Conservation 36:101-113.

723 Powell GVN (1987) Habitat use by wading birds in a subtropical estuary: implications of 724 hydrography. Auk 104:740-749.

725 Powell GVN, Bjork RD, Ogden JC, Paul RT, Powell AH, Robertson WB (1989)

726 Population trends in some Florida Bay wading birds. Wilson Bulletin 101:436-457.

727 Powell GVN, Bjork RD (1996) Great white heron. In: Rodgers JA, Kale HW, Smith HT

728 (eds) Rare and endangered biota of Florida, volume 5: birds. University of Florida

729 Press, Gainesville, pp388-403. 
730 Robertson WB (1993) Florida bay vertebrates -- status reports for great white heron,

731 reddish egret and bald eagle. Everglades National Park, Homestead, Florida.

732 Robblee MB, Barber TB, Carlson PR, Durako MJ, Fourqurean JW, Muehlstein LK,

733 Porter D, Yarbro LA, Zieman RT, Zieman JC. (1991) Mass mortality of the tropical

734 seagrass Thalassia testudinum in Florida Bay (USA). Marine Ecology Progress Series

$735 \quad 71: 297-299$.

736 Rodgers JA, Kale HW, Smith HT (eds) (1996) Rare and endangered biota of Florida,

737 volume 5: birds. University of Florida Press, Gainesville.

738 Ross MS, Meeder JF, Sah JP, Ruiz PL, Telesnicki G (1996) The southeast saline

739 Everglades revisited: a half-century of coastal vegetation change. Vegetation Analysis

740 in the C-111/Taylor Slough Basin. Final Report to the South Florida Water

741 Management District (Contract C-4244), West Palm Beach, Florida.

742 Ross MS. Meeder JF, Sah JP, Ruiz PL, Telesnicki G (2002) The southeast saline

743 Everglades revisited: a half-century of coastal vegetation change. Journal of Vegetation

$744 \quad$ Science

745 Rutherford, ES, Schmidt TW, Tilmant JT (1986) The early life history of spotted

746 seatrout, red drum, gray snapper, and snook in Everglades National Park, Florida.

747 Report SFRC-86/07, South Florida Research Center, Everglades National Park, $748 \quad$ Homestead, Florida.

749 Rutherford, E. S. Tilmant JT, Thue EB, Schmidt TW (1989) Fishery harvest and 750 population dynamics of spotted seatrout, Cynoscion nebulosus, in Florida Bay and 751 adjacent waters. Bulletin of Marine Science 44:108-125. 
752 Serafy JE (1992) Fish assemblages and macrophytes: quantitative investigations in tidal 753 freshwater Chesapeake Bay. Dissertation, University of Maryland.

754 Serafy JE, Lindeman KC, Hopkins TE, Ault JS (1997) Effects of freshwater canal 755 discharge on fish assemblages in a subtropical bay: field and laboratory observations.

756 Marine Ecology Progress Series 160:161-172.

757 Snedaker S, de Sylva D, Cottrell D (1977) A review of the role of fresh water in the 758 estuarine ecosystem. Southwest Florida Water Management District, Brooksville, $759 \quad$ Florida.

760 Sogard SM, Powell GVN, Holmquist JG (1989a) Spatial distribution and trends in 761 abundance of fishes residing in seagrass meadows on Florida Bay mud banks. Bulletin 762 of Marine Science 44:179-199.

763 Sogard SM, Powell GVN, Holmquist JG (1989b) Utilization by fishes of shallow, 764 seagrass-covered banks in Florida Bay: 1. Species composition and spatial 765 heterogeneity. Environmental Biology of Fishes 24:53-65.

766 Stone M, Lorenz JJ (2012) Roseate spoonbills in Florida Bay. South Florida Annual $767 \quad$ Wading Bird Report 12:?-?

768 Swart PK, Healy G, Greer L, Lutz M, Saied A, Anderegg D, Dodge RE, Rudnick D 769 (1999) The use of proxy chemical records in coral skeletons to ascertain past 770 environmental conditions in Florida Bay. Estuaries 22:384-398.

771 Tabb DC, Alexander TR, Thomas TM, Maynard N (1967) The physical, biological, and 772 geological character of the area south of the C-111 Canal in extreme southeastern 773 Everglades National Park, Florida; Report to the U.S. National Park Service (contract 774 NPS 14-10-1-160-11). Everglades National Park, Homestead. 
775 Tebeau CW (1955) The story of the Chokoloskee Bay country, with the reminiscences of

776 pioneer C.S. "Ted" Smallwood. Banyan Books, Miami.

777 Thayer GW, Chester AJ (1989) Distribution and abundance of fishes among basin and

778 channel habitats in Florida Bay. Bulletin of Marine Science, 44:200-219.

779 Thayer GW, Colby DR, Hettler WF (1987) Utilization of the red mangrove prop root

780 habitat by fishes in south Florida. Marine Ecology Progress Series 35:25-38.

781 Thayer GW, Powell AB, Hoss DE (1999) Composition of larval, juvenile, and small

782 adult fishes relative to changes in environmental conditions in Florida Bay. Estuaries

$783 \quad 22: 518-533$.

784 Tilmant JT, Rutherford ES, Thue EB (1989a) Fishery harvest and population dynamics of

785 red drum (Sciaenops ocellatus) from Florida Bay and adjacent waters. Bulletin of

$786 \quad$ Marine Science 44:126-138.

787 Tilmant JT, Rutherford ES, Thue EB (1989b) Fishery harvest and population dynamics of

788 common snook (Centropomus undecimalis) from Florida Bay and adjacent waters.

789 Bulletin of Marine Science. 44:523-524.

790 Torres LG (2009) A kaleidoscope of mammal, bird and fish: habitat use patterns of top

791 predators and their prey in Florida Bay. Marine Ecology Progress Series, 375:289-304.

792 Van Lent TJ, Johnson R, Fennema R (1993) Water management in Taylor Slough and the

793 effects on Florida Bay. Report to South Florida Research Center, Everglades National

794 Park, Homestead.

795 Van Lent TJ, Snow RW, James FE (1999) An examination of the modified water

796 deliveries project, the C-111 project and the experimental water deliveries project: 
797 hydrologic analysis and effects on endangered species. South Florida Natural 798 Resources Center, Everglades National Park, Homestead.

799 Wakeman JM, Wohlschlag DE (1977) Salinity stress and swimming performance of

800 spotted seatrout. Proceedings of the Southeastern Association of Fish and Wildlife $801 \quad$ Agencies 31:357-361.

802 Will LE (1984) A dredgeman of Cape Sable. The Glades Historical Society, Belle Glade.

803 Wood DA (1997) Official lists of endangered and potentially endangered fauna and flora

804 in Florida. Florida Game and Freshwater Fish Commission, Tallahassee, Florida.

805 Worth GAJ (1998) Physiological constraints on the ecology of the West Indian manatee:

806 Potential ramifications for the release of long-term captive manatees. Florida Marine

807 Research Institute, St. Petersburg.

808 Zieman JC, Fourqurean JW, Iverson RL (1989) Distribution, abundance and productivity

809 of seagrasses and macroalgae in Florida Bay. Bulletin of Marine Science 44:292-311.

810 
811 Table 1 Summary of documented and inferred changes to vertebrate populations in Northeastern Florida Bay (NEFB).

\begin{tabular}{|c|c|c|c|c|}
\hline Species/Group & References & Type of evidence & Inferred change from historical & Documented change through time \\
\hline Prey base fishes & $\begin{array}{l}\text { Lorenz 1999, Lorenz } \\
\text { 2000, Lorenz and Serafy } \\
\text { 2006, Lorenz } 2012\end{array}$ & $\begin{array}{l}\text { Inferred from field } \\
\text { studies }\end{array}$ & $\begin{array}{l}\text { Much lower productivity due to } \\
\text { salinity stress, habitat change and } \\
\text { reduced hydroperiod }\end{array}$ & $\begin{array}{l}\text { Freshwater periods are more productive than } \\
\text { periods with saline influence }\end{array}$ \\
\hline Spotted seatrout & Rutherford et al. 1989 & $\begin{array}{l}\text { Inferred from field } \\
\text { studies }\end{array}$ & $\begin{array}{l}\text { Perhaps increased in number due } \\
\text { to a more compatible higher salinity }\end{array}$ & Increased catch rates from 1972 to 1984 \\
\hline Red drum & $\begin{array}{l}\text { Tilmont et al 1989a, } \\
\text { Rutherford et al. } 1989\end{array}$ & $\begin{array}{l}\text { Inferred from field } \\
\text { studies }\end{array}$ & $\begin{array}{l}\text { Decreased due to less freshwater } \\
\text { runoff }\end{array}$ & \\
\hline Common snook & $\begin{array}{l}\text { Tilmont 1989b, } \\
\text { Rutherford et al. } 1989\end{array}$ & $\begin{array}{l}\text { Inferred from field } \\
\text { studies }\end{array}$ & $\begin{array}{l}\text { Decreased due to less freshwater } \\
\text { runoff }\end{array}$ & Declined catch rates from 1972 to 1984 \\
\hline $\begin{array}{l}\text { Mud bank fish } \\
\text { community } \\
\text { structure }\end{array}$ & $\begin{array}{l}\text { Sogard et al 1989, } \\
\text { Matheson et al. } 1999\end{array}$ & Qualitative & & $\begin{array}{l}\text { Changed from benthic to pelagic dominated } \\
\text { spp from } 1984-86 \text { to } 1994-96\end{array}$ \\
\hline $\begin{array}{l}\text { Seagrass fish } \\
\text { community } \\
\text { structure }\end{array}$ & $\begin{array}{l}\text { Thayer and Chester } \\
\text { 1989, Thayer et al. } 1999\end{array}$ & Qualitative & & $\begin{array}{l}\text { Changed from benthic to pelagic dominated } \\
\text { spp from } 1984-85 \text { to } 1994-96\end{array}$ \\
\hline $\begin{array}{l}\text { Mangrove shoreline } \\
\text { fish productivity }\end{array}$ & $\begin{array}{l}\text { Ley 1992, Montegue and } \\
\text { Ley 1993, Ley et al. } 1994\end{array}$ & $\begin{array}{l}\text { Inferred from field } \\
\text { studies }\end{array}$ & $\begin{array}{l}\text { Lowered productivity compared to } \\
\text { historic condition }\end{array}$ & \\
\hline $\begin{array}{l}\text { American crocodile } \\
\text { range }\end{array}$ & $\begin{array}{l}\text { Ogden 1978, Mazzotti } \\
\text { 1999, Mazzotti et al. } 2009\end{array}$ & Quantitative & $\begin{array}{l}\text { Much more abundant and } \\
\text { widespread historically }\end{array}$ & $\begin{array}{l}\text { Nesting range shrank from all of NEFB in } \\
1930 \text { 's to just the coastal mangrove by } 1999 ; \\
\text { population center in ENP shifted from NEFB } \\
\text { to Cape Sable beginning in the early 2000's }\end{array}$ \\
\hline $\begin{array}{l}\text { American crocodile } \\
\text { abundance }\end{array}$ & $\begin{array}{l}\text { Ogden 1978, Mazzotti } \\
\text { and Dunson 1984, Moler } \\
\text { 1991, Mazzotti 1999 }\end{array}$ & $\begin{array}{l}\text { Quantitative, inferred } \\
\text { from field studies }\end{array}$ & $\begin{array}{l}\text { Salinity stress reduced growth rate } \\
\text { and survival of hatchlings and } \\
\text { juveniles resulting in population } \\
\text { decline since } 1984\end{array}$ & $\begin{array}{l}\text { Declined from up to } 2000 \text { historically to less } \\
\text { than } 400 \text { by } 1970 \text {. Modest increases in nest } \\
\text { number since but recovery not as fast as } \\
\text { expected under a more historic flow regime }\end{array}$ \\
\hline Mangrove terrapin & $\begin{array}{l}\text { Dunson and Mazzotti } \\
1989\end{array}$ & $\begin{array}{l}\text { Inferred from } \\
\text { experimental results }\end{array}$ & $\begin{array}{l}\text { Hatchling survival reduced from } \\
\text { historical due to salinity stress }\end{array}$ & \\
\hline $\begin{array}{l}\text { West Indian } \\
\text { manatee }\end{array}$ & $\begin{array}{l}\text { Beard 1938, Hartman } \\
\text { 1974, Odell 1979, Worthy } \\
1998\end{array}$ & $\begin{array}{l}\text { Quantitative, inferred } \\
\text { from field studies }\end{array}$ & $\begin{array}{l}\text { Less use of NEFB due to salinity } \\
\text { stress and salinity induced habitat } \\
\text { changes }\end{array}$ & $\begin{array}{l}\text { Declined from high use in } 1938 \text { to rare in } \\
1990 \text { 's relative to overall population numbers }\end{array}$ \\
\hline
\end{tabular}




\begin{tabular}{|c|c|c|c|c|}
\hline Bottlenose dolphin & Torres 2009 & $\begin{array}{l}\text { Inferred from field } \\
\text { studies }\end{array}$ & $\begin{array}{l}\text { Reduction of preferred prey (see } \\
\text { fish) species may explain minimal } \\
\text { use of the Northeastern Basin }\end{array}$ & \\
\hline Roseate spoonbills & $\begin{array}{l}\text { Lorenz 2000, Lorenz et } \\
\text { al. 2002, Lorenz et al. } \\
2009 \\
\end{array}$ & $\begin{array}{l}\text { Quantitative, inferred } \\
\text { from field studies }\end{array}$ & $\begin{array}{l}\text { Lower nesting success due to } \\
\text { salinity induced declines in prey } \\
\text { number }\end{array}$ & $\begin{array}{l}\text { Decline in the number of nests from } 1259 \text { in } \\
1979 \text { to less than } 350 \text { currently }\end{array}$ \\
\hline Great white heron & $\begin{array}{l}\text { Powell and Powell 1986, } \\
\text { Powell et al } 1989\end{array}$ & $\begin{array}{l}\text { Quantitative, inferred } \\
\text { from field studies }\end{array}$ & $\begin{array}{l}\text { Lowered nest productivity due to } \\
\text { reduced prey base }\end{array}$ & $\begin{array}{l}\text { Significant decline in nesting success in the } \\
\text { mid-1980's compared to early } 1920 \text { 's }\end{array}$ \\
\hline $\begin{array}{l}\text { Eastern brown } \\
\text { pelican }\end{array}$ & $\begin{array}{l}\text { Kushlan and Frohring } \\
1985, \text { Ogden } 1993\end{array}$ & $\begin{array}{l}\text { Quantitative, } \\
\text { qualitative }\end{array}$ & $\begin{array}{l}\text { Were common nesters in NEFB in } \\
1980 \text { 's but have only nested twice } \\
\text { since } 1991\end{array}$ & $\begin{array}{l}\text { Baywide nest numbers declined from } 850 \text { in } \\
1976 \text { to } 350 \text { in } 1993 .\end{array}$ \\
\hline Ospreys & $\begin{array}{l}\text { Ogden 1987, Poole 1989, } \\
\text { Ogden 1993, Bowman et } \\
\text { al. } 1989\end{array}$ & $\begin{array}{l}\text { Quantitative, inferred } \\
\text { from field studies }\end{array}$ & $\begin{array}{l}\text { Reduced nest numbers and nesting } \\
\text { success due to low prey } \\
\text { productivity }\end{array}$ & $\begin{array}{l}\text { Baywide decline from } 200 \text { nests in the } 1970 \text { 's } \\
\text { to } 70 \text { nests; disproportionately larger declines } \\
\text { in NEFB. }\end{array}$ \\
\hline Bald eagle & $\begin{array}{l}\text { Curnutt 1996, Baldwin et } \\
\text { al. } 2012\end{array}$ & Quantitative & & $\begin{array}{l}\text { Consistently about } 30 \text { territories baywide } \\
\text { from } 1958 \text { to mid } 1980 \text { 's then declined to } \\
50 \% \text { occupancy in } 2003 \text {, Territories in NEFB } \\
\text { declined from } 7 \text { to } 1 \text { since mid-1980's. }\end{array}$ \\
\hline
\end{tabular}

812 


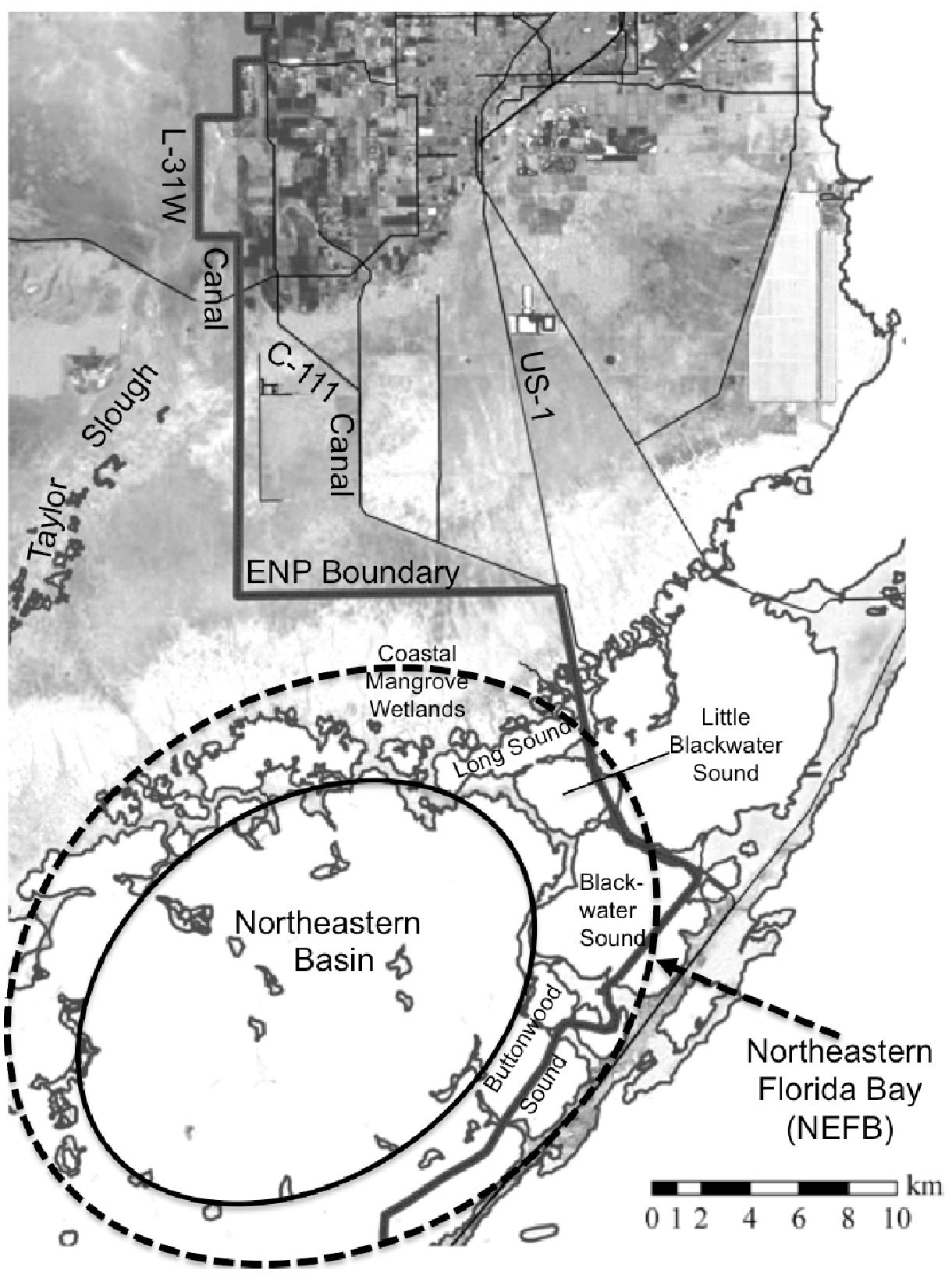

816 Fig 1. Map of northeastern Florida Bay and adjacent Everglades wetlands. The solid line

817 defines the Northeastern Basin and the dashed line defines the Northeastern Florida Bay

818 sub-region (NEFB; as defined by Lorenz 2000). 